\title{
Upregulation of interleukin-13 receptor chains in bronchial smooth muscle tissues of mouse experimental asthma
}

\author{
Yoshihiko CHIBA ${ }^{1}$, Satoshi ONODA ${ }^{1}$, Michiko TodorokI ${ }^{1}$, \\ Yuichi NISHIDA ${ }^{1}$ and Miwa MISAWA ${ }^{1}$ \\ ${ }^{1}$ Department of Pharmacology, School of Pharmacy, Hoshi University, Japan
}

Received November 11, 2009; Accepted December 15, 2009

\begin{abstract}
Interleukin-13 (IL-13) is believed to be a central mediator of the induction of airway hyperresponsiveness (AHR), one of the characteristic features of allergic bronchial asthma. The IL-13-mediated events are mainly generated by its binding to functional IL13 receptor, IL13R $\alpha 1$ chain. In the present study, the changes in the levels of IL-13 receptors in bronchial smooth muscles were determined in mice with AHR induced by antigen inhalation. Mice were sensitized and repeatedly challenged with ovalbumin antigen. Total RNAs of the left main bronchi were extracted, and real-time RT-PCR analyses for IL13R $\alpha 1$ and IL13R $\alpha 2$ chains were conducted. As a result, both the receptor chains were significantly increased in the diseased bronchial smooth muscle. The timecourse analyses revealed that the peaks of IL13R $\alpha 1$ and IL13R $\alpha 2$ upregulations were at 6 hour and 3-12 hour after the last antigen inhalation, respectively. It is thus possible that the IL-13-mediated signaling in bronchial smooth muscle is considerably augmented by the upregulations of IL-13 itself and its functional IL13R $\alpha 1$ receptor in allergic asthmatics.
\end{abstract}

Key words: interleukin-13, IL13R $\alpha 1$, IL13R $\alpha 2$, allergic bronchial asthma, bronchial smooth muscle

\section{Introduction}

Interleukin-13 (IL-13) is a pleiotropic cytokine with a molecular weight of $\sim 11 \mathrm{kDa}$ which shows homology to IL-4 (de Vries, 1996; Minty et al., 1993). Human IL-13 gene is located on chromosome $5 \mathrm{q}$ in a region that has been linked to allergic disorders including bronchial asthma (Palmer et al., 1998; Postma et al., 1995). There is increasing evidence that IL-13 is a central mediator of the induction of airway hyperresponsiveness (AHR) (Chiba et al., 2009a; 2009b; 2009c; Grunig et al., 1998; Wills-Karp et al., 1998; Wills-Karp, 2004), one of the characteristic features of allergic bronchial asthma. An increased expression of IL-13 has been demonstrated in cells of bronchoalveolar lavage fluids obtained from patients with symptomatic

Correspondence to: Yoshihiko Chiba, Ph.D., Department of Pharmacology, School of Pharmacy, Hoshi

University, 2-4-41 Ebara, Shinagawa-ku, Tokyo 142-8501, Japan

Phone: +81-3-5498-5786 Fax: +81-3-5498-5787 e-mail: chiba@hoshi.ac.jp 
asthma (Bodey et al., 1999; Prieto et al., 2000). In addition, overexpression of IL-13 in the airway epithelial cells of mouse using the Clara cell $10-\mathrm{kDa}$ protein gene promoter causes AHR to aerosolized methacholine (Zhu et al., 1999). Intratracheal instillation of recombinant IL-13 to naive mice also evokes AHR to inhaled methacholine (Yang et al., 2001) and intravenously administered $\mathrm{ACh}$ (Wills-Karp et al., 1998). Interestingly, intranasal administration of recombinant IL-13 to the histamine $\mathrm{H}_{1}$ receptor gene-deleted mouse, which fails to develop allergen-induced AHR, also induces AHR (Bryce et al., 2006). Additionally, the neutralization of IL-13 by systemic administration of an antibody against IL-13 (Yang et al., 2004; 2005; Eum et al., 2005) inhibits allergen-induced AHR in sensitized mice. Mice in which targeted deletion of IL13 was performed fail to develop AHR, but AHR is restored by the intranasal administration of recombinant IL-13 (Walter et al., 2001).

Both the IL13R $\alpha 1$ and IL13R $\alpha 2$ chains are expressed in many different hematopoietic and non-hematopoietic cells, including peripheral eosinophils (Myrtek et al., 2004), airway epithelial cells (Zheng et al., 2003) and bronchial smooth muscle cells (Chiba et al., 2009a). Reportedly, in vitro cell analyses revealed that the expressions of IL13R $\alpha 1$ and IL13R $\alpha 2$ chains are dramatically modulated by various cytokines, including IL-13 itself, IL-4, interferon- $\gamma$ (IFN- $\gamma$ ), tumor necrosis factor- $\alpha$ (TNF- $\alpha$ ), and so on (Myrtek et al., 2004; Zheng et al., 2003). However, little is known about the changes in the airway expression of these receptor chains after allergen inhalation in vivo. In the present study, the effects of antigen exposure on the expression levels of IL13R $\alpha 1$ and IL13R $\alpha 2$ chains in bronchial smooth muscle tissues were determined in a mouse model of allergic bronchial asthma.

\section{Methods}

\section{Animals}

Male BALB/c mice were purchased from the Charles River Japan, Inc. (Kanagawa, Japan) and housed in a pathogen-free facility. All animal experiments were approved by the Animal Care Committee of the Hoshi University (Tokyo, Japan).

\section{Antigen sensitization and challenge}

Preparation of a murine model of allergic bronchial asthma was performed as described previously (Chiba et al., 2009a; 2009b; 2009c). In brief, BALBc mice (8 weeks of age) were actively sensitized by intraperitoneal injections of $8 \mu$ g ovalbumin (OA; Seikagaku Co., Tokyo, Japan) with $2 \mathrm{mg}$ Imject Alum (Pierce Biotechnology, Inc., Rockfold, IL, USA) on day 0 and day 5. The sensitized mice were challenged with aerosolized OA-saline solution $(5 \mathrm{mg} / \mathrm{ml})$ for 30 min on days 12,16 and 20. A control group of mice received the same immunization procedure except to inhale saline aerosol instead of OA challenge. The aerosol was generated with an ultrasonic nebulizer (Nihon Kohden, Tokyo, Japan) and introduced to a Plexiglas chamber box $(130 \times 200 \mathrm{~mm}, 100 \mathrm{~mm}$ height $)$ in which the mice were placed. At the indicated time after the last OA challenge, mice were sacrificed by exsanguination from the abdominal aorta under urethane (1.6 g/kg, i.p.; Sigma, St. Louis, MO, USA) anesthesia. 


\section{Real-time RT-PCR analyses}

After the exsanguinations, the left main bronchus of each animal was isolated, and the epithelium was removed as much as possible by the method previously described (Chiba et al., 2009a). Total RNA of the mouse bronchial smooth muscle tissue was isolated with a one-step guanidium-phenol-chloroform extraction procedure using $1 \mathrm{ml}$ of TRI Reagent (Sigma-Aldrich, St. Louis, MO, USA) according to the manufacturer's instructions. The mRNA levels were quantified by real-time RT-PCR. Briefly, cDNAs were prepared from the total RNA (10 ng) using QuantiTect $^{\mathrm{TM}}$ reverse transcription kit (Qiagen Inc., Valencia, CA, USA) according to the manufacturer's instructions. Then the RT reaction mixture $(1 \mu \mathrm{l})$ was subjected to real-time PCR analyses using iQ $^{\mathrm{TM}}$ SYBR Green Supermix (Bio-Rad Laboratories, Hercules, CA, USA) according to the manufacturer's instructions. The thermal cycle profile used was 1) denaturing for $15 \mathrm{sec}$ at $95^{\circ} \mathrm{C}, 2$ ) annealing primers for $30 \mathrm{sec}$ at $55^{\circ} \mathrm{C}$, and 3) extending the primers for 30 sec at $72^{\circ} \mathrm{C}$. The PCR amplification was performed at 40 cycles with monitoring fluorescence. The primer sets used were: QuantiTect Primer Assay, QT00113785 for mouse IL13R $\alpha 1$ chain, QT0019388 for mouse GAPDH (Qiagen Inc., USA), and 5'ACCCATTCCACCAAGGTGTTAC-3' and 5'-GCAGACTCCCAGGAAATATCGT-3' for mouse IL13R $\alpha 2$ chain. The comparative threshold cycle $\left(\mathrm{C}_{\mathrm{T}}\right)$ method was used for relative quantification of the target genes. Differences in the $\mathrm{C}_{\mathrm{T}}$ values $\left(\Delta \mathrm{C}_{\mathrm{T}}\right)$ between the tested gene and the GAPDH were calculated to determine the relative expression levels, using the following formula: $\Delta \Delta \mathrm{C}_{\mathrm{T}}=\left(\Delta \mathrm{C}_{\mathrm{T}}\right.$ of the treated sample $)-\left(\Delta \mathrm{C}_{\mathrm{T}}\right.$ of the control sample). The relative expression level between the samples was calculated according to the equation $2^{-\Delta \Delta \mathrm{CT}}$.

\section{Statistical analyses}

All the data were expressed as the mean with S.E. Statistical significance of difference was determined by two-way analysis of variance (ANOVA) with post hoc Bonferroni/Dunn (StatView for Macintosh ver. 5.0, SAS Institute, Inc., NC, USA). A value of $P<0.05$ was considered significant.

\section{Results}

Effect of antigen exposure on the mRNA levels of IL13R $\alpha 1$

The real-time RT-PCR analyses revealed that the expression level of IL13R $\alpha 1$ chain was increased in bronchial smooth muscle tissues of the antigen-challenged mice (Fig. 1, upper panel). A significant increase ( 2.5-fold of the control) was observed at 6 hour after the last antigen challenge. Then the increment was gradually decreased, but was still greater ( 1.5-fold of the control) 24 hour after the antigen challenge (Fig. 1, upper panel).

\section{Effect of antigen exposure on the mRNA levels of IL13R $\alpha 2$}

The real-time RT-PCR analyses also revealed a significant increase in the level of IL13R $\alpha 2$ chain in the diseased bronchial smooth muscle tissues (Fig. 1, lower panel). The increment was relatively greater (60- to 70-fold of the control) and lasting (3-12 hour after the challenge) than that in the case of IL13R $\alpha 1$. The level of IL13R $\alpha 2$ chain was still higher at 24 hour after the 


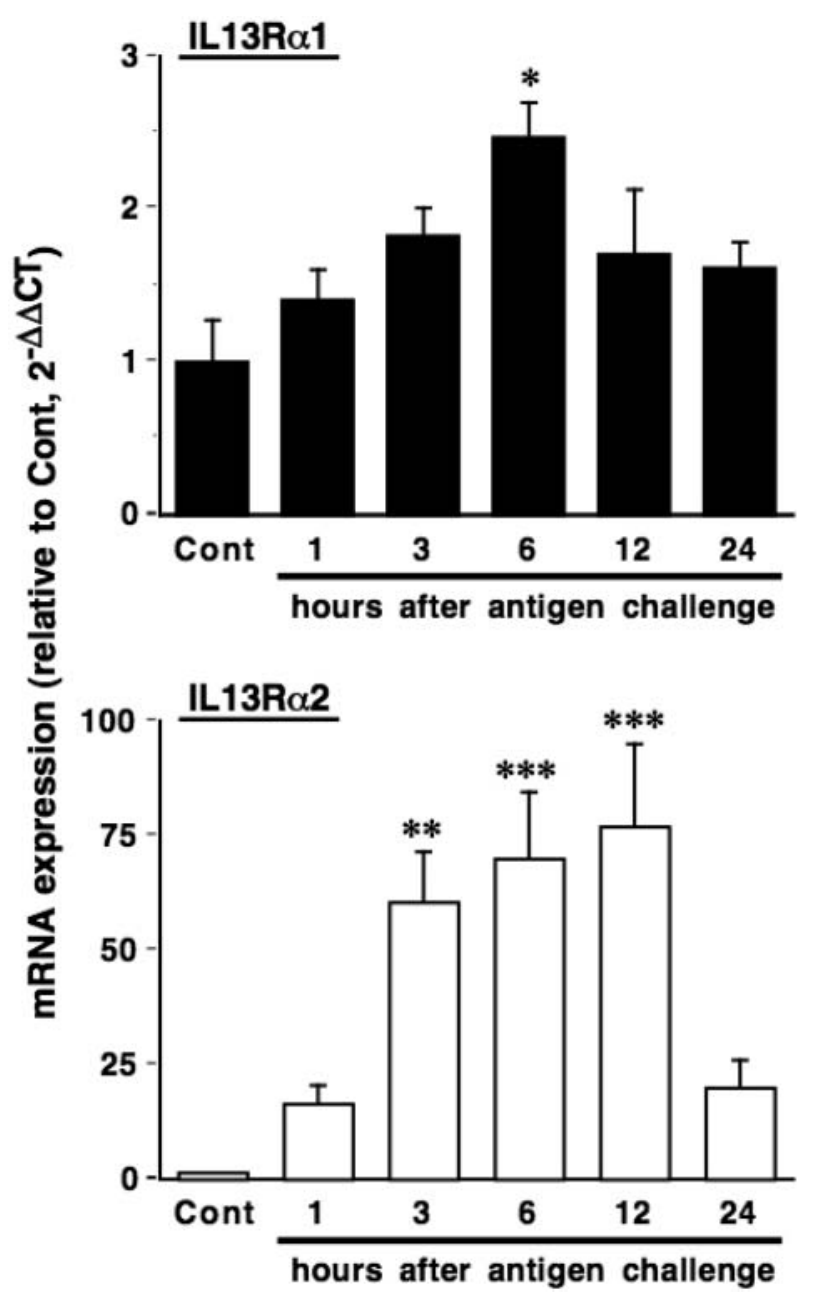

Fig. 1. Changes in the mRNA levels for IL13R $\alpha 1$ (upper) and IL13R $\alpha 2$ chains (lower) in smooth muscle tissues of the left main bronchi in mice. Total RNAs were extracted from the bronchial tissues at 1, 3, 6, 12 and 24 hour after the last antigen challenge. The gene expressions were determined by quantitative real-time RT-PCR. The relative expressions of target genes to GAPDH mRNAs were calculated by the $2^{-\Delta \Delta C T}$ methods, respectively, as described in Method section. Results are presented as the mean \pm S.E. from 4-6 different animals. *, $P<0.05$; ${ }^{* *} ; P<0.01$ and ${ }^{* *}, P<0.001$ vs. respective control (Cont) by Bonferroni/Dunn test.

antigen challenge ( 20 -fold of the control), although the difference was not statistically significant (Fig. 1, lower panel).

\section{Discussion}

Airway smooth muscle is an important effector tissue regulating bronchomotor tone. It has been suggested that modulation of airway smooth muscle by inflammatory mediators such as cytokines may play an important role in the development of airway hyperresponsiveness (AHR) 
(Amrani and Panettieri, 2002). Indeed, recent studies revealed that IL-13 has an ability to cause hyperresponsiveness of airway smooth muscles (Chiba et al., 2009a; Deshpande et al., 2004; Tliba et al., 2003,). Our previous study also revealed an increase in IL-13 in bronchoalveolar lavage fluids of the antigen-challenged mice (Chiba et al., 2009c). It is thus possible that IL-13, generated by allergen exposure in the airways, directly acts on airway smooth muscles and causes AHR in vivo. We show here that antigen inhalation to sensitized mice also caused an upregulation of IL13R $\alpha 1$ chain, a major functional receptor that mediates IL-13-induced intracellular signalings, in bronchial smooth muscle tissue (Fig. 1). Taken together, the IL-13mediated signaling in bronchial smooth muscles might be considerably augmented by the upregulations of IL-13 itself and its own functional receptors after the antigen exposure.

The current observation that IL13R $\alpha 1$ chain is upregulated in the diseased bronchial smooth muscle (Fig. 1) might provide us a key strategy for the treatment of asthma, especially hyperresponsiveness of bronchial smooth muscle. There is increasing evidence that a small GTPase RhoA is involved in the contraction of airway smooth muscle, and that an augmented contraction due to the upregulated RhoA protein is a cause of AHR (Chiba et al., 1999; Chiba and Misawa, 2004). RhoA and its downstream Rho-kinases are now considered as therapeutic targets of asthma (Kume, 2008; Schaafsma et al., 2008). We have previously reported that treatment with IL-13 caused an upregulation of RhoA via an activation of STAT6 in bronchial smooth muscle cells (Chiba et al., 2009a; 2009c). Thus, inhibition of the activation of IL13R 1 (which is upregulated in the diseased bronchial smooth muscle as shown in Fig. 1) and/or its downstream signaling (which is probably enhanced due to the upregulated IL13R $\alpha 1$ in the diseased bronchial smooth muscle) might have therapeutic potential for AHR in asthmatics.

In the present study, a marked upregulation of IL13R $\alpha 2$ chain was also demonstrated in bronchial smooth muscle tissues of repeatedly antigen-challenged mice (Fig. 1, lower panel). It has been believed that IL13R $\alpha 2$ is a decoy receptor for IL-13 (Feng et al., 1998; Wills-Karp, 2004). Indeed, overexpression of IL13R $\alpha 2$ diminished the IL-13 signaling (Kawakami et al., 2001). Conversely, antigen-induced asthma phenotypes were deteriorated in mice lacking IL13R 2 (Zheng et al., 2008). Since IL13R $\alpha 2$ expression is stimulated by various Th2 cytokines (Zheng et al., 2003), which are commonly upregulated in the airways of human asthmatics and mouse models of asthma (Bochner et al., 1994), IL13R $\alpha 2$ might serve as a negative feedback mechanism even at the level of bronchial smooth muscle. On the other hand, functional role of IL13R $\alpha 2$ has also been suggested (Fichtner-Feigl et al., 2006). Further studies are needed to define the role of IL13R $\alpha 2$ in the development of bronchial smooth muscle hyperresponsiveness.

In conclusion, both IL13R $\alpha 1$ and IL13R $\alpha 2$ chains are upregulated in bronchial smooth muscles of mice with experimental asthma. Targeting of the functional IL13R $\alpha 1$ and/or its downstream signaling molecules might be effective in the treatment of AHR, one of the characteristic features of allergic bronchial asthma.

\section{Acknowledgement}

This work was supported by the Ministry of Education, Culture, Sports, Science and Technology of Japan. 


\section{References}

Amrani, Y. and Panettieri, R.A.Jr. (2002). Modulation of calcium homeostasis as a mechanism for altering smooth muscle responsiveness in asthma. Curr. Opin. Allergy Clin. Immunol. 2: 39-45.

Bochner, B.S., Undem, B.J. and Lichtenstein, L.M. (1994). Immunological aspects of allergic asthma. Annu. Rev. Immunol. 12: 295-335.

Bodey, K.J., Semper, A.E., Redington, A.E., Madden, J., Teran, L.M., Holgate, S.T. and Frew, A.J. (1999). Cytokine profiles of BAL T cells and T-cell clones obtained from human asthmatic airways after local allergen challenge. Allergy 54: 1083-1093.

Bryce, P.J., Mathias, C.B., Harrison, K.L., Watanabe, T., Geha, R.S. and Oettgen, H.C. (2006). The $\mathrm{H}_{1}$ histamine receptor regulates allergic lung responses. J. Clin. Invest. 116: 1624-1632.

Chiba, Y. and Misawa, M. (2004). The role of RhoA-mediated $\mathrm{Ca}^{2+}$ sensitization of bronchial smooth muscle contraction in airway hyperresponsiveness. J. Smooth Muscle Res. 40: 155-167.

Chiba, Y., Nakazawa, S., Todoroki, M., Shinozaki, K., Sakai, H. and Misawa, M. (2009a). Interleukin-13 augments bronchial smooth muscle contractility with an up-regulation of RhoA protein. Am. J. Respir. Cell Mol. Biol. 40: 159-167.

Chiba, Y., Takada, Y., Miyamoto, S., MitsuiSaito, M., Karaki, H. and Misawa, M. (1999). Augmented acetylcholine-induced, Rho-mediated $\mathrm{Ca}^{2+}$ sensitization of bronchial smooth muscle contraction in antigen-induced airway hyperresponsive rats. Br. J. Pharmacol. 127: 597-600.

Chiba, Y., Tanabe, M., Goto, K., Sakai, H. and Misawa, M. (2009b). Down-regulation of miR-133a contributes to up-regulation of RhoA in bronchial smooth muscle cells. Am. J. Respir. Crit. Care Med. 180: 713-719.

Chiba, Y., Todoroki, M., Nishida, Y., Tanabe, M. and Misawa, M. (2009c). A Novel STAT6 inhibitor AS1517499 ameliorates antigen-induced bronchial hypercontractility in mice. Am. J. Respir. Cell Mol. Biol. 41: 516-524.

de Vries, J.E. (1996). Molecular and biological characteristics of interleukin-13. Chem. Immunol. 63 : 204-218.

Deshpande, D.A., Dogan, S., Walseth, T.F., Miller, S.M., Amrani, Y., Panettieri, R.A. and Kannan, M.S. (2004). Modulation of calcium signaling by interleukin-13 in human airway smooth muscle: role of CD38/cyclic adenosine diphosphate ribose pathway. Am. J. Respir. Cell Mol. Biol. 31: 36-42.

Eum, S.Y., Maghni, K., Tolloczko, B., Eidelman, D.H. and Martin, J.G. (2005). IL-13 may mediate allergen-induced hyperresponsiveness independently of IL-5 or eotaxin by effects on airway smooth muscle. Am. J. Physiol. 288: L576-L584.

Feng, N., Lugli, S.M., Schnyder, B., Gauchat, J.F., Graber, P., Schlagenhauf, E., Schnarr, B., WiederkehrAdam, M., Duschl, A., Heim, M.H., Lutz, R.A. and Moser, R. (1998). The interleukin-4/ interleukin-13 receptor of human synovial fibroblasts: overexpression of the nonsignaling interleukin-13 receptor alpha2. Lab. Invest. 78: 591-602.

Fichtner-Feigl, S., Strober, W., Kawakami, K., Puri, R.K. and Kitani, A. (2006). IL-13 signaling through the IL-13alpha2 receptor is involved in induction of TGF-beta1 production and fibrosis. Nat. Med. 12: 99-106.

Grunig, G., Warnock, M., Wakil, A.E., Venkayya, R., Brombacher, F., Rennick, D.M., Sheppard, D., Mohrs, M., Donaldson, D.D., Locksley, R.M. and Corry, D.B. (1998). Requirement for IL-13 independently of IL-4 in experimental asthma. Science 282: 2261-2263.

Kawakami, K., Taguchi, J., Murata, T. and Puri, R.K. (2001). The interleukin-13 receptor alpha2 chain: an essential component for binding and internalization but not for interleukin-13-induced signal transduction through the STAT6 pathway. Blood 97: 2673-2679.

Kume, H. (2008). RhoA/Rho-kinase as a therapeutic target in asthma. Curr. Med. Chem. 15: 2876-2885.

Minty, A., Chalon, P., Derocq, J.M., Dumont, X., Guillemot, J.C., Kaghad, M., Labit, C., Leplatois, P., Liauzun, P., Miloux, B., Minty, C., Casellas, P., Loison, G., Lupker, J., Shire, D., Ferrara, P. and Caput, D. (1993). Interleukin-13 is a new human lymphokine regulating inflammatory and 
immune responses. Nature 362: 248-250.

Myrtek, D., Knoll, M., Matthiesen, T., Krause, S., Lohrmann, J., Schillinger, D., Idzko, M., Virchow, J.C., Friedrich, K. and Luttmann, W. (2004). Expression of interleukin-13 receptor alpha 1-subunit on peripheral blood eosinophils is regulated by cytokines. Immunology 112: 597-604.

Palmer, L.J., Daniels, S.E., Rye, P.J., Gibson, N.A., Tay, G.K., Cookson, W.O., Goldblatt, J., Burton, P.R. and LeSouef, P.N. (1998). Linkage of chromosome 5q and 11q gene markers to asthmaassociated quantitative traits in Australian children. Am. J. Respir. Crit. Care Med. 158: 18251830 .

Postma, D.S., Bleecker, E.R., Amelung, P.J., Holroyd, K.J., Xu, J., Panhuysen, C.I., Meyers, D.A. and Levitt, R.C. (1995). Genetic susceptibility to asthma-bronchial hyperresponsiveness coinherited with a major gene for atopy. N. Engl. J. Med. 333: 894-900.

Prieto, J., Lensmar, C., Roquet, A., van der Ploeg, I., Gigliotti, D., Eklund, A. and Grunewald, J. (2000). Increased interleukin-13 mRNA expression in bronchoalveolar lavage cells of atopic patients with mild asthma after repeated low-dose allergen provocations. Respir. Med. 94: 806-814.

Schaafsma, D., Roscioni, S.S., Meurs, H. and Schmidt, M. (2008). Monomeric G-proteins as signal transducers in airway physiology and pathophysiology. Cell. Signal. 20: 1705-1714.

Tliba, O., Deshpande, D., Chen, H., Van Besien, C., Kannan, M., Panettieri, R.A.Jr. and Amrani, Y. (2003). IL-13 enhances agonist-evoked calcium signals and contractile responses in airway smooth muscle. Br. J. Pharmacol. 140: 1159-1162.

Walter, D.M., McIntire, J.J., Berry, G., McKenzie, A.N., Donaldson, D.D., DeKruyff, R.H. and Umetsu, D.T. (2001). Critical role for IL-13 in the development of allergen-induced airway hyperreactivity. J. Immunol. 167: 4668-4675.

Wills-Karp, M. (2004). Interleukin-13 in asthma pathogenesis. Immunol. Rev. 202: 175-190.

Wills-Karp, M., Luyimbazi, J., Xu, X., Schofield, B., Neben, T.Y., Karp, C.L. and Donaldson, D.D. (1998). Interleukin-13: central mediator of allergic asthma. Science 282: 2258-2261.

Yang, M., Hogan, S.P., Henry, P.J., Matthaei, K.I., McKenzie, A.N., Young, I.G., Rothenberg, M.E. and Foster, P.S. (2001). Interleukin-13 mediates airways hyperreactivity through the IL-4 receptoralpha chain and STAT-6 independently of IL-5 and eotaxin. Am. J. Respir. Cell Mol. Biol. 25: 522-530.

Yang, G., Li, L., Volk, A., Emmell, E., Petley, T., Giles-Komar, J., Rafferty, P., Lakshminarayanan, M., Griswold, D.E., Bugelski, P.J. and Das, A.M. (2005). Therapeutic dosing with anti-interleukin-13 monoclonal antibody inhibits asthma progression in mice. J. Pharmacol. Exp. Ther. 313: 8-15.

Yang, G., Volk, A., Petley, T., Emmell, E., Giles-Komar, J., Shang, X., Li, J., Das, A.M., Shealy, D., Griswold, D.E. and Li, L. (2004). Anti-IL-13 monoclonal antibody inhibits airway hyperresponsiveness, inflammation and airway remodeling. Cytokine 28: 224-232.

Zheng, T., Liu, W., Oh, S.Y., Zhu, Z., Hu, B., Homer, R.J., Cohn, L., Grusby, M.J. and Elias, J.A. (2008). IL-13 receptor alpha2 selectively inhibits IL-13-induced responses in the murine lung. $J$. Immunol. 180: 522-529.

Zheng, T., Zhu, Z., Liu, W., Lee, C.G., Chen, Q., Homer, R.J. and Elias, J.A. (2003). Cytokine regulation of IL-13Ralpha2 and IL-13Ralpha1 in vivo and in vitro. J. Allergy Clin. Immunol. 111: 720-728.

Zhu, Z., Homer, R.J., Wang, Z., Chen, Q., Geba, G.P., Wang, J., Zhang, Y. and Elias, J.A. (1999). Pulmonary expression of interleukin-13 causes inflammation, mucus hypersecretion, subepithelial fibrosis, physiologic abnormalities, and eotaxin production. J. Clin. Invest. 103: $779-788$. 